\title{
Peat bogs as hotspots for organoarsenical formation and persistence
}

Mikutta, Christian; Rothwell, James J.

Published in:

Environmental Science \& Technology

DOI:

10.1021/acs.est.5b06182

Publication date:

2016

Document version

Publisher's PDF, also known as Version of record

Citation for published version (APA):

Mikutta, C., \& Rothwell, J. J. (2016). Peat bogs as hotspots for organoarsenical formation and persistence.

Environmental Science \& Technology, 50(8), 4314-4323. https://doi.org/10.1021/acs.est.5b06182 


\title{
Peat Bogs as Hotspots for Organoarsenical Formation and Persistence
}

\author{
Christian Mikutta* ${ }^{\dagger,+}$ and James J. Rothwell ${ }^{\S}$ \\ ${ }^{\dagger}$ Section for Environmental Chemistry and Physics, Department of Plant and Environmental Sciences, University of Copenhagen, \\ DK-1871 Frederiksberg C, Denmark \\ ${ }^{\ddagger}$ Soil Chemistry Group, Institute of Biogeochemistry and Pollutant Dynamics, Department of Environmental Systems Science, CHN, \\ ETH Zurich, 8092 Zurich, Switzerland \\ ${ }^{\S}$ Upland Environments Research Unit, Geography, School of Environment, Education and Development, The University of \\ Manchester, Manchester M13 9PL, U.K.
}

\section{Supporting Information}

\begin{abstract}
Peatlands have received significant atmospheric inputs of As and S since the onset of the Industrial Revolution, but the effect of $S$ deposition on the fate of As is largely unknown. It may encompass the formation of As sulfides and organosulfur-bound As, or the indirect stimulation of As biotransformation processes, which are presently not considered as important As immobilization pathways in wetlands. To investigate the immobilization mechanisms of anthropogenically derived As in peatlands subjected to long-term atmospheric pollution, we explored the solid-phase speciation of As, Fe, and S in English peat bogs by X-ray absorption spectroscopy. Additionally, we analyzed the speciation of As in pore- and streamwaters. Linear combination fits of extended X-ray absorption fine structure (EXAFS) data imply that $62-100 \%$ (average: $82 \%$ ) of solid-phase As (As $s_{\text {tot }}$ : 9-92 mg/kg) was present as organic As(V) and As(III). In agreement with appreciable concentrations of organoarsenicals in surface waters $\left(\mathrm{pH}: 4.0-4.4, \mathrm{E}_{\mathrm{h}}\right.$ :

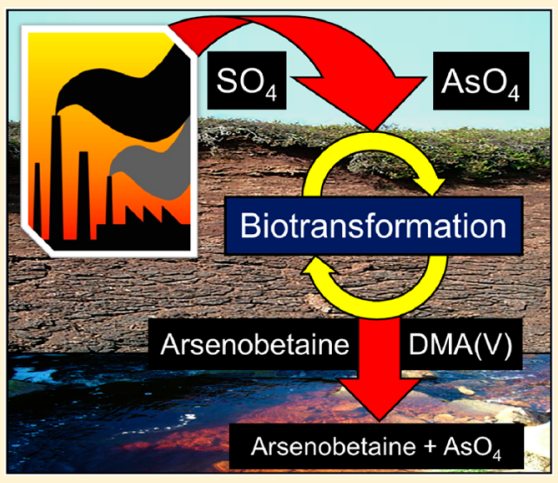
165-190 mV, average $A s_{\text {tot }}: 1.5-129 \mu \mathrm{g} / \mathrm{L}$ ), our findings reveal extensive biotransformation of atmospheric As and the enrichment of organoarsenicals in the peat, suggesting that the importance of organometal(loid)s in wetlands subjected to prolonged air pollution is higher than previously assumed.
\end{abstract}

\section{INTRODUCTION}

Peatlands represent the most widespread group of wetlands, covering $\sim 3 \%$ of the Earth's total land area. ${ }^{1}$ They provide essential ecosystem services, including organic carbon $\left(\mathrm{C}_{\text {org }}\right)$ storage, biodiversity protection, and water budget regulation. They also play a significant role in the biogeochemical cycling of trace elements. ${ }^{2-4}$ Peatlands of the Northern Hemisphere have been impacted by emissions associated with coal-burning, smelting, and other anthropogenic activities. Consequently, many peatland environments exhibit elevated concentrations of trace elements, including the potentially carcinogenic metalloid As. Arsenic in anthropogenically impacted peatlands typically reaches concentration levels of several tens of $\mathrm{mg} / \mathrm{kg}^{5-7}$ comparable to As-contaminated rice paddies in Southeast Asia, ${ }^{8}$ and can jeopardize water resources. ${ }^{9}$ Despite decades of intensive As research, the impact of anthropogenically derived, atmospherically deposited As on the biogeochemical As cycle is largely unknown, particularly the effect of atmospheric $S$ codeposition, triggered by the release of sulfur dioxide $\left(\mathrm{SO}_{2}\right)$ from coal-burning. In the U.K., for example, acid rain associated with historical industrial $\mathrm{SO}_{2}$ and $\mathrm{NO}_{x}$ emissions, has modified the chemistry of sensitive peatlands, and led to a loss of plant diversity. ${ }^{10}$ The effect of sulfate $\left(\mathrm{SO}_{4}\right)$ deposition on the speciation and mobility of As in peatlands is unclear: Anoxic peatlands may serve as a sink for $\mathrm{S}$ through $\mathrm{SO}_{4}$ reduction, thus potentially sequestering As in sulfide minerals ${ }^{11}$ or facilitating its binding to sulfhydryl groups (R-SH) of organic matter $(\mathrm{OM}) .^{12,13}$ Since increased $\mathrm{S}$ deposition can increase methylation rates of $\mathrm{Hg}$ by sulfate-reducing bacteria in peatlands, ${ }^{14,15}$ biomethylation of As may be another important process in peatlands subjected to long-term deposition of both As and $\mathrm{S}$. The formation of volatile (methyl)arsines $\left(\mathrm{H}_{3-n}\left(\mathrm{CH}_{3}\right)_{n} \mathrm{As}, n=0-3\right)$, the end product of microbial As biomethylation which transforms inorganic As into simple methylated As compounds, ${ }^{16}$ is a common process in wetlands. ${ }^{17,18}$ Fluxes of (methyl)arsines emitted from peatlands have been estimated to $\leq 2980 \mathrm{mg}$ As/ha/y. ${ }^{17,18}$ Although data on organoarsenical stores in atmospherically impacted peatlands are entirely missing, biomethylation of As is currently not considered an important As immobilization process in wetlands. ${ }^{19}$ In order to explore the fate of anthropogenic As in peatlands influenced by significant $S$ deposition, we determined the speciation of $\mathrm{As}, \mathrm{Fe}$, and $\mathrm{S}$ in peat bogs

Received: December 17, 2015

Revised: February 27, 2016

Accepted: March 7, 2016

Published: April 1, 2016 

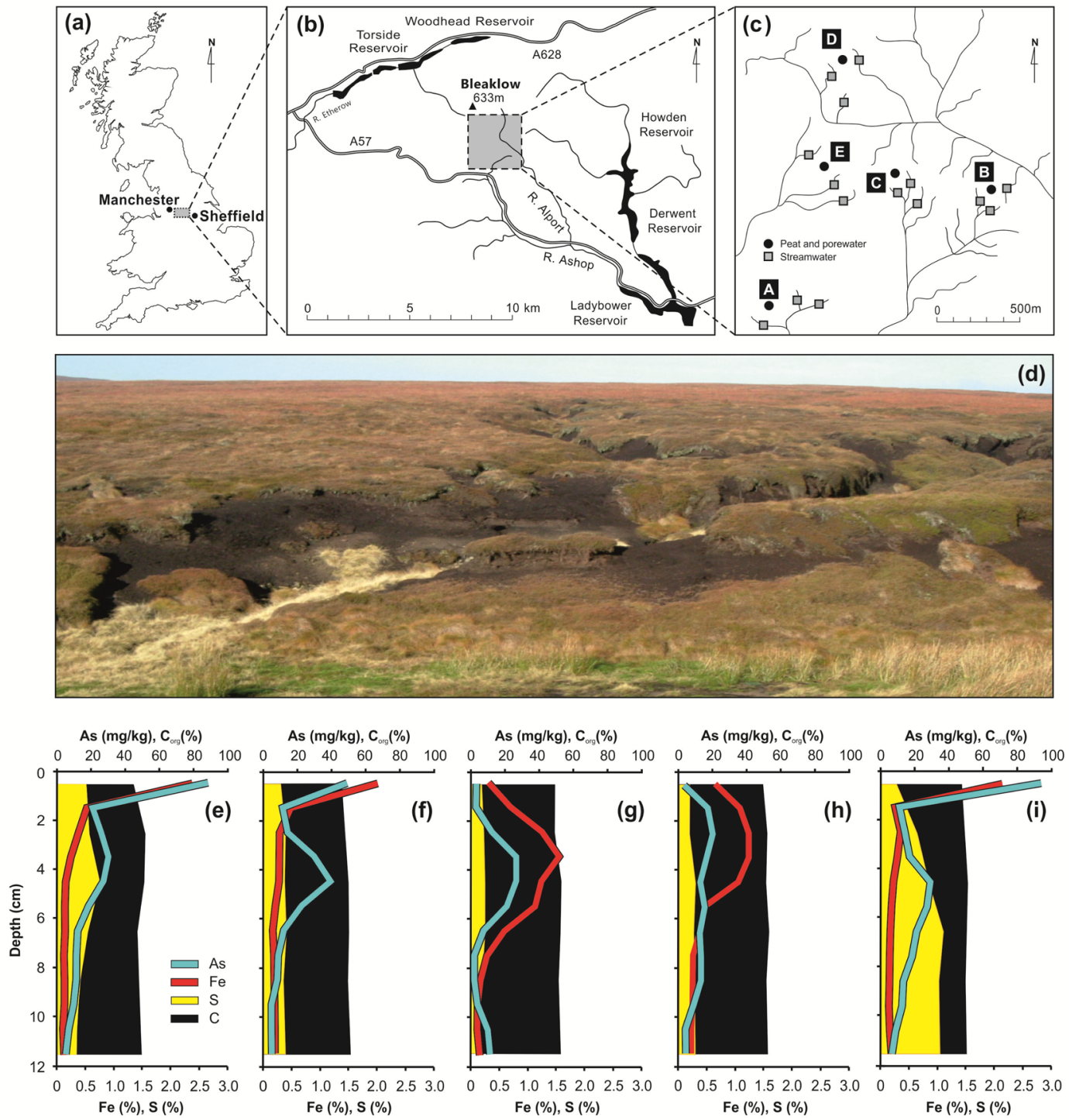

Figure 1. Field site in the Peak District, England, with elemental distributions of As, organic C, Fe, and S for five peat cores. (a) Location of the Peak District situated between the industrial cities of Manchester and Sheffield. (b) Bleaklow within the Peak District showing the major rivers and reservoirs, which supply drinking water to Greater Manchester, the East Midlands, and South Yorkshire. (c) Overview of peat (solid and porewater phases) and streamwater sampling sites (A-E) with the headwater drainage network. (d) Panoramic view of the peat bog environment at site $\mathrm{C}$, where Eriophorum is the main vegetation type. Incising peat gullies which form the drainage network are also evident. (e-i) Vertical distributions of As, $\mathrm{C}_{\text {org }}, \mathrm{Fe}$, and $\mathrm{S}$ for sites $\mathrm{A}, \mathrm{B}, \mathrm{C}, \mathrm{D}$, and $\mathrm{E}$, respectively. Element distributions are presented on a dry weight basis.

(ombrotrophic peatlands) of the Peak District, England, which is situated in the heartland of the 19th Century English Industrial Revolution (Figure 1). During this time, the rapid growth of the cities of Manchester, Leeds, and Sheffield led to gross air pollution. ${ }^{20}$ Sulfur deposition from coal-burning peaked at the start of the 20th Century, with values $>150 \mathrm{~kg}$ $\mathrm{S} / \mathrm{ha} / \mathrm{y}$ in this region. ${ }^{10}$ Owing to high levels of atmospheric pollution throughout the period of industrial growth, ${ }^{10}$ peat bogs of the Peak District are extensively contaminated with trace metal(loids)s, including As. ${ }^{7,21}$ This pollution history renders these peatlands a prime locality to explore whether long-term codeposition of As and S has triggered the formation of As sulfides or organosulfur-bound As in the peats, or instead resulted in the formation and storage of methylated As species-analogous to $\mathrm{Hg}^{15}$ Therefore, we used X-ray absorption spectroscopy (XAS) and wet chemical analyses to determine the speciation of As in the peat solid and aqueous phase as well as in peatland streamwaters.

\section{MATERIALS AND METHODS}

Sampling. Peat monoliths and surface waters were collected at five sites (A-E) with varying moisture conditions (Figure 1, Supporting Information (SI) Table S1). The location and characteristics of the sites are documented in the SI. Extruded monoliths (11 cm diameter, $15 \mathrm{~cm}$ depth, PVC tube) were immediately sealed with airtight rubberized end-caps and transported to the laboratory at $-18{ }^{\circ} \mathrm{C}$ using a portable freezer (Waeco CoolFreeze CDF-11). Only relatively short peat monoliths were required as this depth encompasses the As-contaminated zone in Peak District peat bogs. ${ }^{7}$ A composite sample of peat porewater from the upper peat $(0-5 \mathrm{~cm})$ was collected at three replicate locations within a $50 \mathrm{~cm}$ radius of each peat monolith. This depth was chosen to represent the 

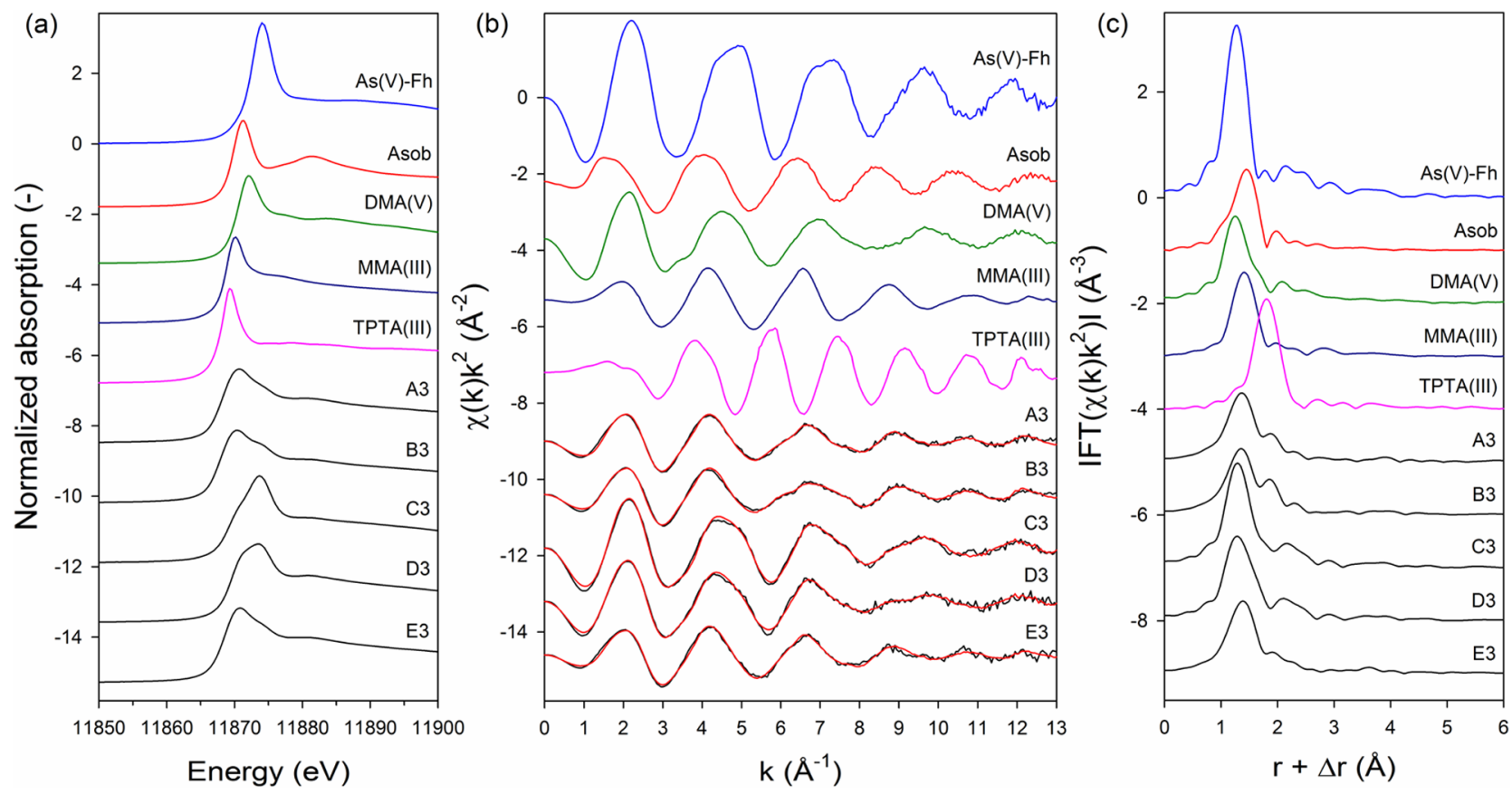

Figure 2. Arsenic speciation in the studied peat samples. (a) Normalized As K-edge XANES spectra of selected As(V) and As(III) reference compounds and peat samples originating from different sites and a depth of 4-5 cm. Abbreviations and white-line maximum positions of the reference compounds: $\mathrm{As}(\mathrm{V})-\mathrm{Fh}=$ arsenate-adsorbed ferrihydrite $(11874.1 \mathrm{eV})$, Asob = arsenobetaine $(11871.2 \mathrm{eV}), \mathrm{DMA}(\mathrm{V})=\mathrm{dimethylarsinic}$ acid $(11872.1 \mathrm{eV}), \mathrm{MMA}(\mathrm{III})=$ monomethylarsonous acid $(11870.1 \mathrm{eV})$, and TPTA(III) = tris(phenylthio)arsine $(11869.4 \mathrm{eV})$. (b) Arsenic K-edge EXAFS spectra of LCF reference compounds and peat samples $\left(E_{0}=11875 \mathrm{eV}\right)$. Linear combination fits of the samples are shown as red lines. The fits of all peat samples are illustrated in Figure S7 and their results are reported in Table 1. (c) Magnitudes of the Fourier-transformed EXAFS spectra calculated over $k=2-11 \AA^{-1}$ using a Hanning window function with a sill width of $2 \AA^{-1}$.

acrotelm zone of the peat bog, which is associated with oxic/ suboxic conditions due to a fluctuating water table, high hydraulic conductivity, and runoff production. ${ }^{22}$ Given that long equilibrium times (days to weeks) are often required for in situ porewater sampling in peat bogs ${ }^{23}$ and the vertical resolution of porewater geochemistry was not required, a modified squeezing approach suitable for peats was used to collect the porewaters. ${ }^{24}$ The upper $5 \mathrm{~cm}$ of peat was extruded using a PVC tube $(7 \mathrm{~cm}$ diameter) with a predrilled port close to the base. An end-cap was immediately placed on the base and a rubberized plunger was used to apply pressure by hand. Porewater was collected in a syringe attached to the basal port. The waters were passed through $0.2 \mu \mathrm{m}$ filters (Whatman) onsite into sterile polypropylene (PP) vials without head space and transported to the laboratory under refrigerated conditions in the portable freezer. At each of the five sampling sites, water samples were collected from three headwater streams draining the peat bogs (Figure 1) using new $500 \mathrm{~mL}$ HDPE bottles (Nalgene) that had been prerinsed with deionized water (ELGA Purelab Option R7). Water samples were collected from the center of the stream channel and $\sim 10 \mathrm{~cm}$ below the water surface. Bottles were rinsed with streamwater prior to sample collection. Subsamples for the various analyses described below were filtered on-site into PP vials without head space and transported back to laboratory under refrigerated conditions.

Aqueous-Phase Analyses. Redox potential and $\mathrm{pH}$ were determined on-site on unfiltered water samples. Total As (As $\left.s_{\text {tot }}\right)$ and $\mathrm{Fe}$ concentrations in pore- and streamwaters were determined by ICP-MS and ICP-AES, respectively, following acidification with double-distilled $\mathrm{HNO}_{3}$ to $2 \%$ (v/v) (BDH). Aqueous inorganic and organic As species (arsenite, arsenate,
$\operatorname{MMA}(\mathrm{V}), \operatorname{DMA}(\mathrm{V})$, and arsenobetaine) were determined by anion exchange HPLC-ICP-MS. Total carbon (TC) in the water samples was determined with a total organic carbon analyzer. Dissolved organic carbon (DOC) was calculated by subtracting inorganic carbon from TC. Sulfate and $\mathrm{NO}_{3}$ were determined by ion chromatography. Details on the aqueousphase measurements are provided in the SI.

Solid-Phase Analyses. Peat samples for total element determination were sliced at contiguous one centimeter intervals with a stainless steel blade and then freeze-dried (Christ Alpha 1-2 LD plus). Peat samples were disaggregated with a mortar and pestle, and then finely ground and homogenized with an agate ball mill (Fritsch Pulverisette 0). Milled peat was then mixed with wax binder (Licowax C Micropowder) and pressed into $40 \mathrm{~mm}$ pellets for major and trace element determination by XRF (PANalytical Axios sequential X-ray fluorescence spectrometer). A certified low ash peat reference material ${ }^{25}$ was analyzed with each sample batch. Element concentrations were within $10 \%$ of certified values. Total $\mathrm{C}, \mathrm{N}$, and $\mathrm{S}$ contents were determined in triplicate using a CHNS elemental analyzer (Leco CHNS-932). Mean relative standard deviations of these measurements were $1 \%$ (C), 4\% (N), and 9\% (S) $(n=25)$. Selected peat samples from the surface and subsurface zone at each of the five sites were examined using a FEI/Philips XL30 environmental scanning electron microscope equipped with an EDAX Gemini energydispersive X-ray spectroscopy (EDS) system. Therefore, intact one centimeter thick peat samples were air-dried, mounted onto $\mathrm{Al}$ specimen stubs and then carbon coated.

Based on XRF results, a subset of peat samples was selected and prepared for XAS analyses. The preparation included freeze-drying and milling (as above) and subsequent filling into 
Table 1. Linear Combination Fit Results for $k^{2}$-Weighted As K-edge EXAFS Spectra of the Studied Peat Samples. ${ }^{a}$

\begin{tabular}{|c|c|c|c|c|c|c|c|c|c|}
\hline sample & depth & As & Fe-bound inorganic $\mathrm{As}^{b}$ & organic $\operatorname{As}(V)^{c}$ & organic As(III) ${ }^{d}$ & $\sum$ organic As & $\mathrm{S}_{\text {org }}$-bound As(III) ${ }^{e}$ & red. $\chi^{2 f}$ & $\mathrm{NSSR}^{g}$ \\
\hline & $(\mathrm{cm})$ & $(\mathrm{mg} / \mathrm{kg})$ & (atom\%) & (atom\%) & (atom\%) & (atom\%) & (atom\%) & $\left(\times 10^{3}\right)$ & $(\%)$ \\
\hline $\mathrm{A} 2$ & $2-3$ & 24 & $17(7)$ & $37(0 / 37 / 0)$ & 47 & 83 & 0 & 3.6 & 2.1 \\
\hline A3 & $4-5$ & 25 & 0 & $33(0 / 33 / 0)$ & 51 & 84 & $9(7)^{h}$ & 1.7 & 1.6 \\
\hline A4 & $6-7$ & 10 & 0 & $57(44 / 13 / 0)$ & 27 & 84 & 16 & 5.9 & 5.5 \\
\hline B2 & $2-3$ & 14 & 0 & $53(18 / 35 / 0)$ & 42 & 95 & 5 & 5.6 & 4.3 \\
\hline B3 & $4-5$ & 40 & $5(5)$ & $37(0 / 37 / 0)$ & 39 & 75 & 20 & 1.7 & 1.7 \\
\hline B4 & $6-7$ & 12 & 0 & $40(13 / 27 / 0)$ & 43 & 82 & 18 & 3.8 & 3.4 \\
\hline $\mathrm{C} 2$ & $2-3$ & 12 & $30(0)$ & $40(0 / 40 / 0)$ & 31 & 70 & 0 & 6.7 & 2.3 \\
\hline $\mathrm{C} 3$ & $4-5$ & 26 & $26(0)$ & $43(0 / 35 / 7)$ & 31 & 74 & 0 & 3.9 & 1.3 \\
\hline $\mathrm{C} 4$ & $6-7$ & 9 & $19(0)$ & $61(44 / 0 / 18)$ & 20 & 81 & 0 & 5.0 & 3.1 \\
\hline D3 & $4-5$ & 10 & $18(0)$ & $56(17 / 40 / 0)$ & 25 & 82 & 0 & 3.7 & 1.8 \\
\hline D4 & $6-7$ & 10 & 0 & $78(36 / 42 / 0)$ & 22 & 100 & 0 & 7.6 & 5.2 \\
\hline D5 & $8-9$ & 10 & $14(0)$ & $78(62 / 16 / 0)$ & 7 & 86 & 0 & 12 & 6.9 \\
\hline E1 & $0-1$ & 92 & $38(0)$ & $50(0 / 50 / 0)$ & 12 & 62 & 0 & 6.4 & 1.8 \\
\hline $\mathrm{E} 2$ & $2-3$ & 15 & $3(3)$ & $34(0 / 34 / 0)$ & 50 & 84 & 13 & 3.3 & 2.9 \\
\hline E3 & $4-5$ & 27 & $7(7)$ & $28(0 / 28 / 0)$ & 56 & 84 & 9 & 3.4 & 2.9 \\
\hline
\end{tabular}

${ }^{a}$ Fit range: $0.5-12.5 \AA^{-1}$. Fit fractions were normalized to a component sum of $100 \%$. Initial fit sums were $99-118 \%(\bar{x}=107 \%)$. Fit fractions are accurate within \pm 10 atom\% at best (see SI). ${ }^{b}$ Fit references: Arsenate- and arsenite-adsorbed ferrihydrite. Values in parentheses indicate the percentage of arsenite. ${ }^{c}$ Fit references: Arsenobetaine, dimethylarsinic acid, and monomethylarsonic acid disodium salt. Their respective fit fractions are shown in parentheses $(\mathrm{a} / \mathrm{d} / \mathrm{m}) .{ }^{d}$ Fit reference: Monomethylarsonous acid. ${ }^{e}$ Fit reference: Tris(phenylthio)arsine. ${ }^{f}$ Fit accuracy $\left(\right.$ reduced $\left.\chi^{2}\right) .{ }^{60}$

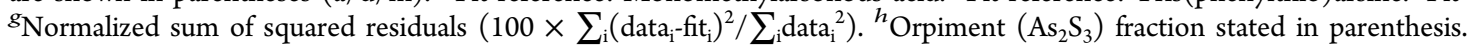

$\mathrm{Al}$ sample holders. Until the end of the XAS measurements the samples were kept under anoxic conditions. Bulk As K-edge (11867 eV), Fe K-edge (7112 eV), and S K-edge $(2472 \mathrm{eV})$ XAS spectra were collected at cryogenic temperatures at beamlines 11-2 (As), 4-1 (Fe), and 4-3 (S) of the Stanford Synchrotron Radiation Lightsource (SSRL, Menlo Park, CA, USA). Arsenic and Fe extended X-ray absorption fine structure (EXAFS) spectra were analyzed by linear combination fitting (LCF) in Athena ${ }^{26}$ after principal component analysis and target-transform testing (PCA-TT) ${ }^{27}$ in SIXPack. ${ }^{28}$ EXAFS shell-fit analyses were performed in Artemis, ${ }^{26}$ and spectral deconvolutions of normalized S X-ray absorption near edge structure (XANES) spectra were carried out in WinXAS 3.2. ${ }^{29}$ Details on XAS data collection, reduction, and analyses are given in the SI.

\section{RESULTS AND DISCUSSION}

Down-Core Trends. The down-core trends in total As, $\mathrm{C}_{\text {org }}, \mathrm{Fe}$, and $\mathrm{S}$ concentrations are shown in Figure 1, and Figures S1 and S2 display the concentrations of major and trace elements in the peat. Arsenic concentrations in the peat ranged from $<1$ to $92 \mathrm{mg} / \mathrm{kg}$, with an average of $15 \mathrm{mg} / \mathrm{kg}$ (Figure 1). The three wettest sites (A, B, and E; Table S1) exhibited similar solid-phase As distributions. Arsenic maxima at these sites occurred at the peat surface $(0-1 \mathrm{~cm})$ and were synchronous with the Fe peak. This distribution pattern likely originates from postdepositional mobilization and lateral transport of As since these sites are located on gentle foot slopes and thus receive water via near-surface flow pathways in the acrotelm. ${ }^{21}$ In contrast, As and Fe maxima at the drier sites $\mathrm{C}$ and $\mathrm{D}$ occurred below the surface, between depths of $2-5 \mathrm{~cm}$. All down-core trends of As at depths $>2 \mathrm{~cm}$ broadly mirrored those of $\mathrm{Pb}$ (Figure S2), whose maxima in Peak District peat bogs have been dated to $\sim 1900 \mathrm{AD}$ - the climax of the English Industrial Revolution. ${ }^{21}$ Down-core trends in $S$ were neither correlated with Fe nor As (Figure 1).

Solid-Phase Arsenic Speciation. Figure 2 shows As Kedge XANES and EXAFS spectra of As(III) and As(V) reference compounds and peat samples from 4 to $5 \mathrm{~cm}$ depth. The XANES spectra of the peat samples exhibited white-line maxima which fell in between those of arsenate-adsorbed ferrihydrite $(11874.1 \mathrm{eV})$ and tris(phenylthio)arsine (11869.4 $\mathrm{eV})$, a compound in which $\mathrm{As}(\mathrm{III})$ is coordinated to three $\mathrm{S}$ atoms at a distance, $r$, of 2.26(1) $\AA^{12}$ (Figure 2a). The broad white lines in the peat XANES spectra indicate mixtures of triand pentavalent As, the latter being more abundant in samples C3 and D3 originating from the drier sites (Figure 2a, Table S1). All peat samples showed comparatively small Fouriertransform peaks at $\sim 1.3 \AA$, which are characteristic of $\mathrm{O} / \mathrm{C}$ pair correlations of alkylated As compounds such as arsenobetaine or dimethylarsinic acid, $\mathrm{DMA}(\mathrm{V})$ (Figure 2c). In order to determine the major As species and their corresponding fractions in the peat, we analyzed the As EXAFS spectra by means of LCF. This XAS data evaluation method provides semiquantitative estimates of major coordination environments of the target element. Potential As species in the peat were elucidated by PCA-TT analyses based on a spectra set of 15 peat samples and a comprehensive library of As reference compounds (see SI). Our results revealed the presence of four major coordination environments of As representing $\mathrm{Fe}$ associated inorganic As, organic As(V), organic As(III), and As(III) associated with reduced organic $S$ (' $\mathrm{S}_{\text {org }}$-bound As(III)'). The LCF results are summarized in Table 1 and selected fits are illustrated in Figure $2 b$. Accordingly, the peat contained $0-38 \%$ Fe-bound arsenite/arsenate $(\bar{x}=12 \%), 28-$ $78 \%$ organic $\operatorname{As}(\mathrm{V})(\bar{x}=48 \%), 7-56 \%$ organic $\operatorname{As}(\mathrm{III})(\bar{x}=$ $34 \%)$, and $0-20 \% S_{\text {org }}$-bound As(III) $(\bar{x}=6 \%)$. Arsenate associated with Fe was most abundant at site $\mathrm{C}(19-30 \%)$ and the top centimeter of site $\mathrm{E}(38 \%)$ (Table 1$)$. The fit reference 'arsenate-adsorbed ferrihydrite' implies that arsenate is sorbed to $\mathrm{Fe}$ (III)-(oxyhydr)oxides, ${ }^{30} \mathrm{Fe}$ (III)-OM complexes, ${ }^{31}$ and/ or-to a lesser extent-Fe sulfides ${ }^{32}$ (see Fe speciation section and SI section 7). Despite a correlation between down-core As and Fe concentrations (Figure 1), the identification of autigenic and allogenic Fe particles in the peat (Figure S3) and 1.73$24.8 \mathrm{~g} / \mathrm{kg} \mathrm{Fe}$ in samples analyzed by As XAS (Table S2), the 


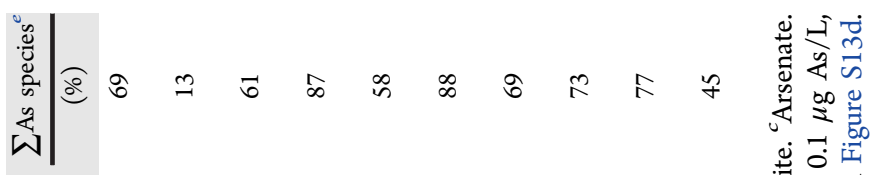

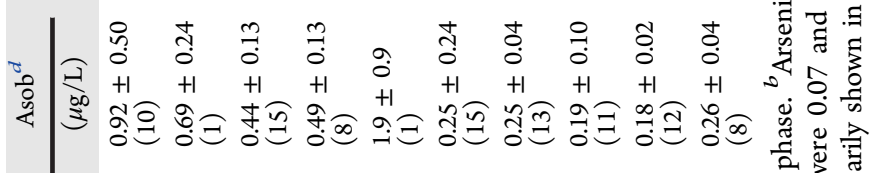

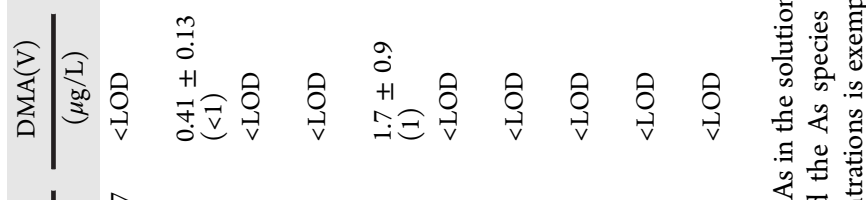

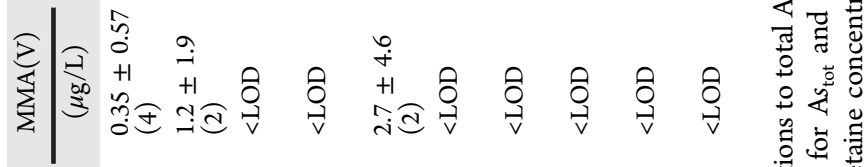

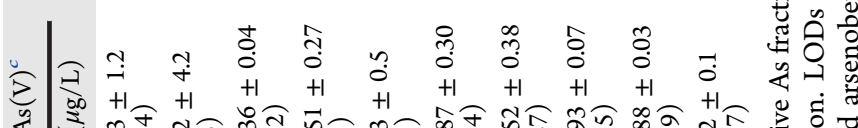

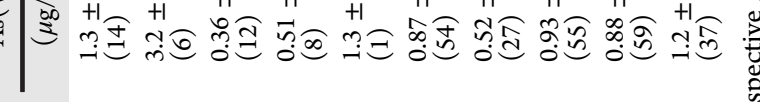

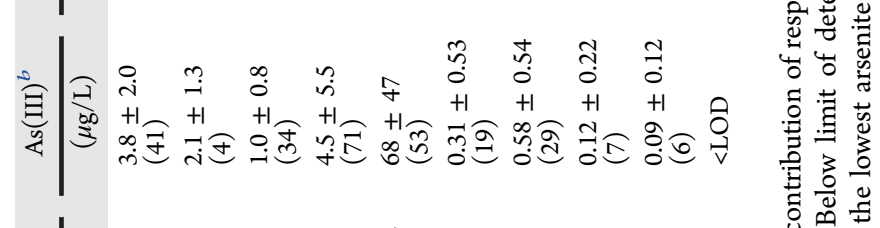

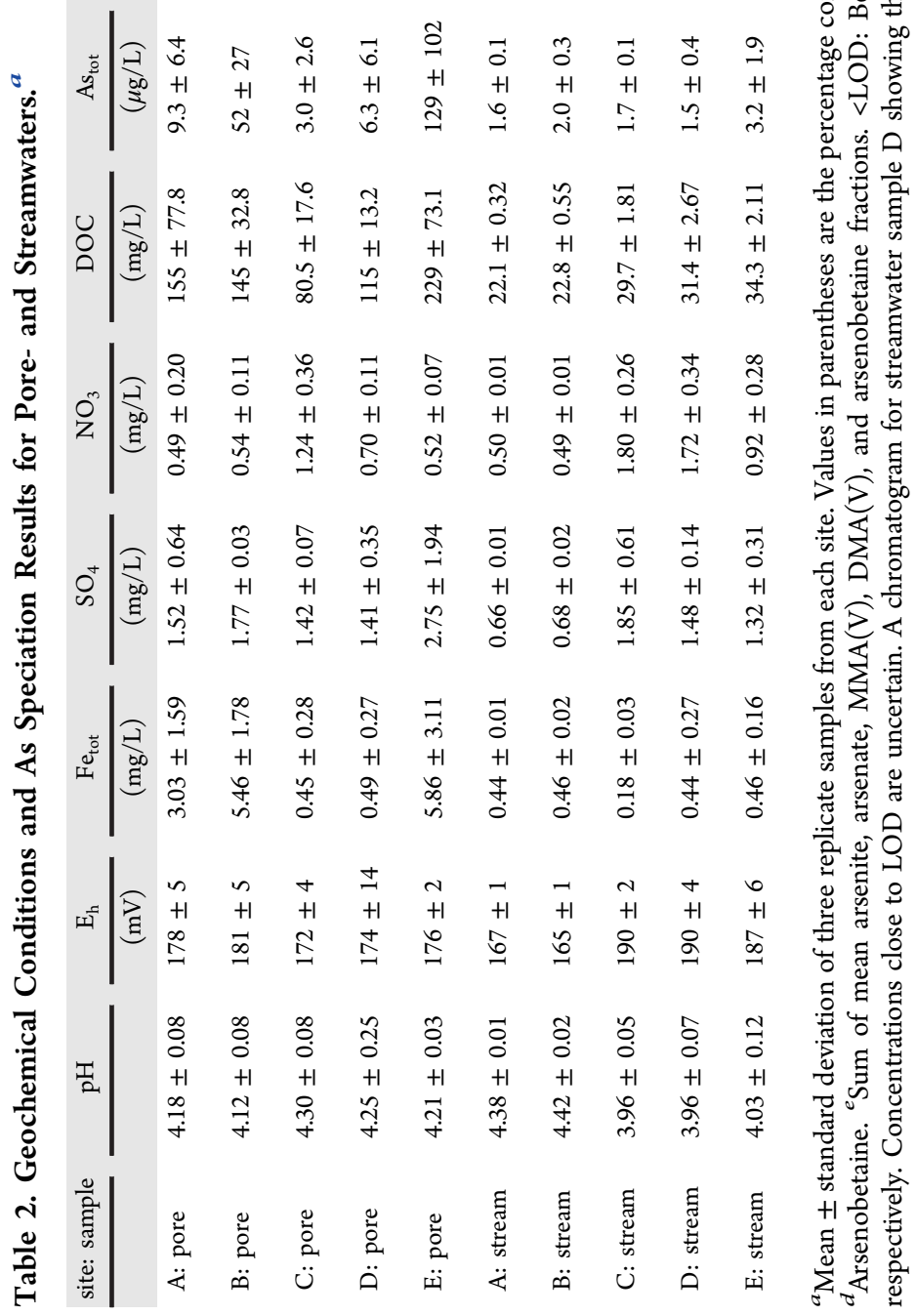



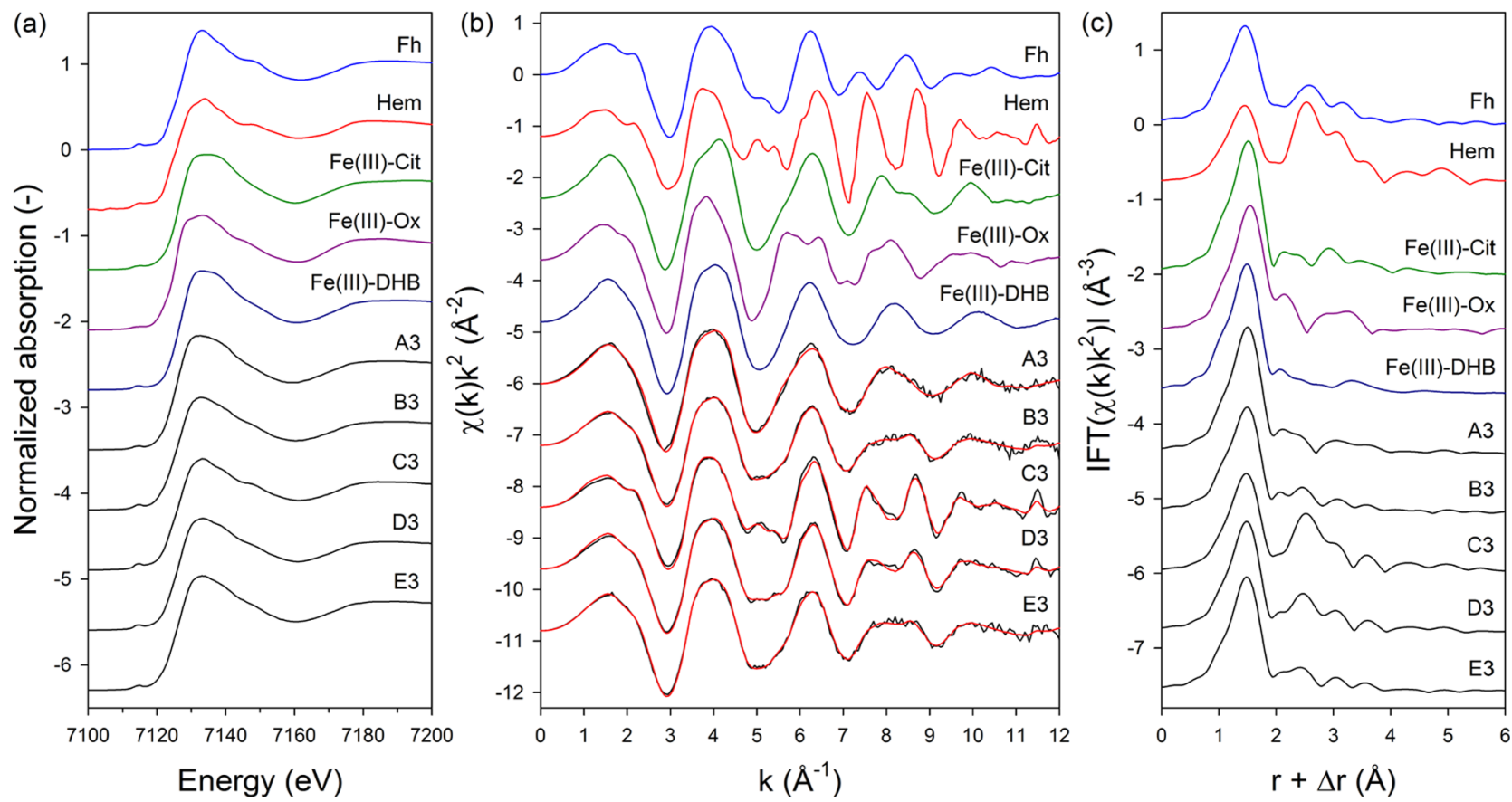

Figure 3. Iron speciation in the studied peat samples. (a) Normalized Fe K-edge XANES spectra of Fe(III) reference compounds used for linear combination fitting and select peat samples originating from different sites and a depth of $4-5 \mathrm{~cm}$. Abbreviation of reference compounds: Fh $=$ ferrihydrite, $\mathrm{Hem}=$ hematite, $\mathrm{Fe}(\mathrm{III})$-Cit = Fe(III)-citrate, $\mathrm{Fe}(\mathrm{III})-\mathrm{Ox}=\mathrm{Fe}(\mathrm{III})$-oxalate, $\mathrm{Fe}(\mathrm{III})$ - DHB = Fe(III)-3,4-dihydroxybenzoate. (b) Iron Kedge EXAFS spectra of the reference compounds and peat samples $\left(E_{0}=7130 \mathrm{eV}\right)$. Linear combination fits are shown as red lines. The fits of all peat samples are illustrated in Figure S12 and their results are summarized in Table 3. (c) Magnitudes of the Fourier-transformed EXAFS spectra calculated over $k=2-11 \AA^{-1}$ using a Hanning window function with a sill width of $2 \AA^{-1}$.

majority of As was not associated with Fe. Except for one sample, As was not found to exist in sulfide phases either, despite elevated $\mathrm{S}$ contents (Tables 1 and $\mathrm{S} 2$ ) and the presence of S-rich particles in the peat (Figure S3). Instead, organic As constituted $62-100 \%(\bar{x}=82 \%)$ of total As (Table 1). Our data thus provide the first evidence for organic As species dominating the solid-phase As speciation in wetlands characterized by low As contents (Table 1). Reference compounds employed for organic As species in the LCF analyses comprised arsenobetaine, dimethylarsinic acid, monomethlyarsononic acid disodium salt (MMA(V)), and monomethylarsonous acid (MMA(III)). The arsenobetaine and $\operatorname{DMA}(\mathrm{V})$ references alone were fit with up to 62 and $50 \%$, respectively (Table 1). In arsenobetaine (hydrate) As is present as arsonium cation coordinated to three methyl groups $\left(\mathrm{CH}_{3}\right)$ and one methanediyl group $\left(\mathrm{CH}_{2}\right)\left(r_{\mathrm{As}-\mathrm{C}}=1.86(1)-1.92(1) \AA\right.$, $\bar{x}=1.90 \AA) \cdot{ }^{33}$ In DMA(V) As is coordinated to two methyl groups $\left(r_{\mathrm{As}-\mathrm{C}}=1.895(2) \AA\right)$ and two oxygens $\left(r_{\mathrm{As}-\mathrm{O}}=\right.$ $1.662(2)$ and $1.720(2) \AA, \bar{x}=1.691 \AA) .{ }^{34}$ EXAFS shell-fit analyses of samples from sites $\mathrm{C}$ and $\mathrm{D}$ confirmed our LCF results: On average about $1.4 \pm 0.5 \mathrm{O}$ atoms and $2.2 \pm 0.7 \mathrm{C}$ atoms were fit at $1.69 \pm 0.01 \AA \AA$ and $1.89 \pm 0.02 \AA$, respectively $(\bar{x} \pm \sigma, n=6)$ (Figure S8 and Table S5). The As-C distances are in agreement with those found in arsenobetaine hydrate and $\mathrm{DMA}(\mathrm{V})$, whereas the As-O distances comply with DMA(V), arsenate-adsorbed ferrihydrite, ${ }^{35}$ and the relatively low As(III) contents in these samples (Table 1). The suitability of arsenobetaine as a fit reference suggests that arsonium compounds such as arsenobetaine, arsenocholine, the tetramethylarsonium ion (TETRA), and/or arsenosugars/-lipids prevail in the peat, in addition to simple methylated As compounds. In accordance with our LCF and shell-fit results, peat extractions confirmed the presence of substantial amounts of arsenobetaine $(1.21-7.08 \mathrm{mg} \mathrm{As} / \mathrm{kg}, \bar{x}=3.58 \mathrm{mg} / \mathrm{kg})$ and DMA(V) $(0.47-4.05 \mathrm{mg} \mathrm{As} / \mathrm{kg}, \bar{x}=1.73 \mathrm{mg} / \mathrm{kg})$ in the peat samples (Table S8).

Terrestrial and aquatic plants show a high variation in the relative abundance of As species. Arsenite and arsenate are frequently detected in water or water/methanol extracts of plant tissue, in addition to $\mathrm{MMA}(\mathrm{V}), \mathrm{DMA}(\mathrm{V})$, trimethylarsine oxide (TMAO), arsenobetaine, arsenocholine, and arsenoriboses. ${ }^{36-40}$ However, arsonium compounds are typically far less abundant in plants and As-methylating bacteria ${ }^{41}$ as compared to the simple methylated arsenicals. Thus, arsenobetaine formation in peat bogs likely involves organisms of intermediate trophic levels such as fungi ${ }^{38}$ or plankton, ${ }^{42}$ the latter being supported by strong As accumulation in algae observed in streams of a minerotrophic peatland. ${ }^{43}$ Cultivable fungi in the upper layer of Peak District peats are typically in the range of $1 \times 10^{6} \mathrm{CFU} / \mathrm{g}$ soil with Ascomycota and Basidiomycota dominating the fungal community structure. ${ }^{44}$ In marine environments, arsenobetaine formation has been linked to As detoxification and its role as an osmolyte, and postulated to result from arsenosugar degradation or the synthesis from dimethylarsinous acid (DMA(III)) and 2-oxo acids (glyoxylate and pyruvate). ${ }^{45}$

In all peat samples MMA(III) was fit with up to $56 \%$ (Table 1), indicating the presence of high proportions of methylated As(III) species in the peat. The fit fractions of MMA(III) were significantly lower at the drier sites $\mathrm{C}$ and $\mathrm{D}$ as compared to sites with more sustained water saturation (sites $\mathrm{A}$, $\mathrm{B}$, and $\mathrm{E}$; Table S1) ( $t$-test, one-tailed $p=0.007)$. In concert with large fractions of DMA(V) in all peat samples, these results accord with the Challenger pathway ${ }^{16,46}$ in which microbially absorbed arsenate is initially reduced to arsenite which then undergoes stepwise oxidative methylation and 
Table 3. Linear Combination Fit Results for $k^{2}$-Weighted Fe K-edge EXAFS Spectra of the Studied Peat Samples ${ }^{a}$

\begin{tabular}{|c|c|c|c|c|c|c|c|}
\hline sample & depth & $\mathrm{Fe}$ & $\mathrm{Fe}(\mathrm{III})_{\text {org }}^{b}$ & $\mathrm{Fh}^{c}$ & $\mathrm{Hem}^{d}$ & red. $\chi^{2 e}$ & $\operatorname{NSSR}^{f}$ \\
\hline & $(\mathrm{cm})$ & $(\mathrm{g} / \mathrm{kg})$ & (atom\%) & (atom\%) & (atom\%) & $\left(\times 10^{3}\right)$ & $(\%)$ \\
\hline $\mathrm{A} 3$ & $4-5$ & 2.05 & $100(47 / 23 / 30)$ & 0 & 0 & 4.0 & 1.4 \\
\hline B3 & $4-5$ & 2.82 & $57(31 / 6 / 21)$ & 33 & 10 & 3.1 & 0.3 \\
\hline $\mathrm{C} 3$ & $4-5$ & 12.2 & $9(9 / 0 / 0)$ & 42 & 49 & 4.2 & 1.7 \\
\hline D3 & $4-5$ & 10.3 & $40(40 / 0 / 0)$ & 35 & 25 & 2.0 & 0.8 \\
\hline D4 & $6-7$ & 3.16 & $100(51 / 0 / 49)$ & 0 & 0 & 3.5 & 1.1 \\
\hline D5 & $8-9$ & 1.84 & $100(46 / 0 / 54)$ & 0 & 0 & 3.2 & 1.0 \\
\hline E1 & $0-1$ & 24.8 & $100(45 / 8 / 47)$ & 0 & 0 & 2.7 & 0.9 \\
\hline $\mathrm{E} 2$ & $2-3$ & 3.30 & $43(0 / 0 / 43)$ & 27 & 30 & 3.6 & 1.8 \\
\hline E3 & $4-5$ & 1.87 & $67(26 / 8 / 33)$ & 20 & 13 & 2.6 & 1.1 \\
\hline
\end{tabular}

${ }^{a}$ Fit range: $1.5-12.0 \AA^{-1}$. Fit fractions were normalized to a component sum of $100 \%$. Initial fit sums were $92-107 \%(\bar{x}=99 \%)$. Fit fractions are accurate within \pm 10 atom\% at best. ${ }^{b}$ Organic $\mathrm{Fe}(\mathrm{III})$ complexes. Fit references: $\mathrm{Fe}$ (III)-citrate, $\mathrm{Fe}$ (III)-oxalate, and Fe(III)-3,4-dihydroxybenzoate. Their respective fit fractions are shown in parentheses $(\mathrm{c} / \mathrm{o} / \mathrm{d}) .{ }^{c}$ Ferrihydrite. ${ }^{d}$ Hematite. ${ }^{e}$ Fit accuracy (reduced $\left.\chi^{2}\right) .{ }^{60} f_{\text {Normalized sum of squared }}$ residuals $\left(100 \times \sum_{\mathrm{i}}\left(\text { data }_{\mathrm{i}}-\mathrm{fit}_{\mathrm{i}}\right)^{2} / \sum_{\mathrm{i}} \mathrm{data}_{\mathrm{i}}^{2}\right)$.
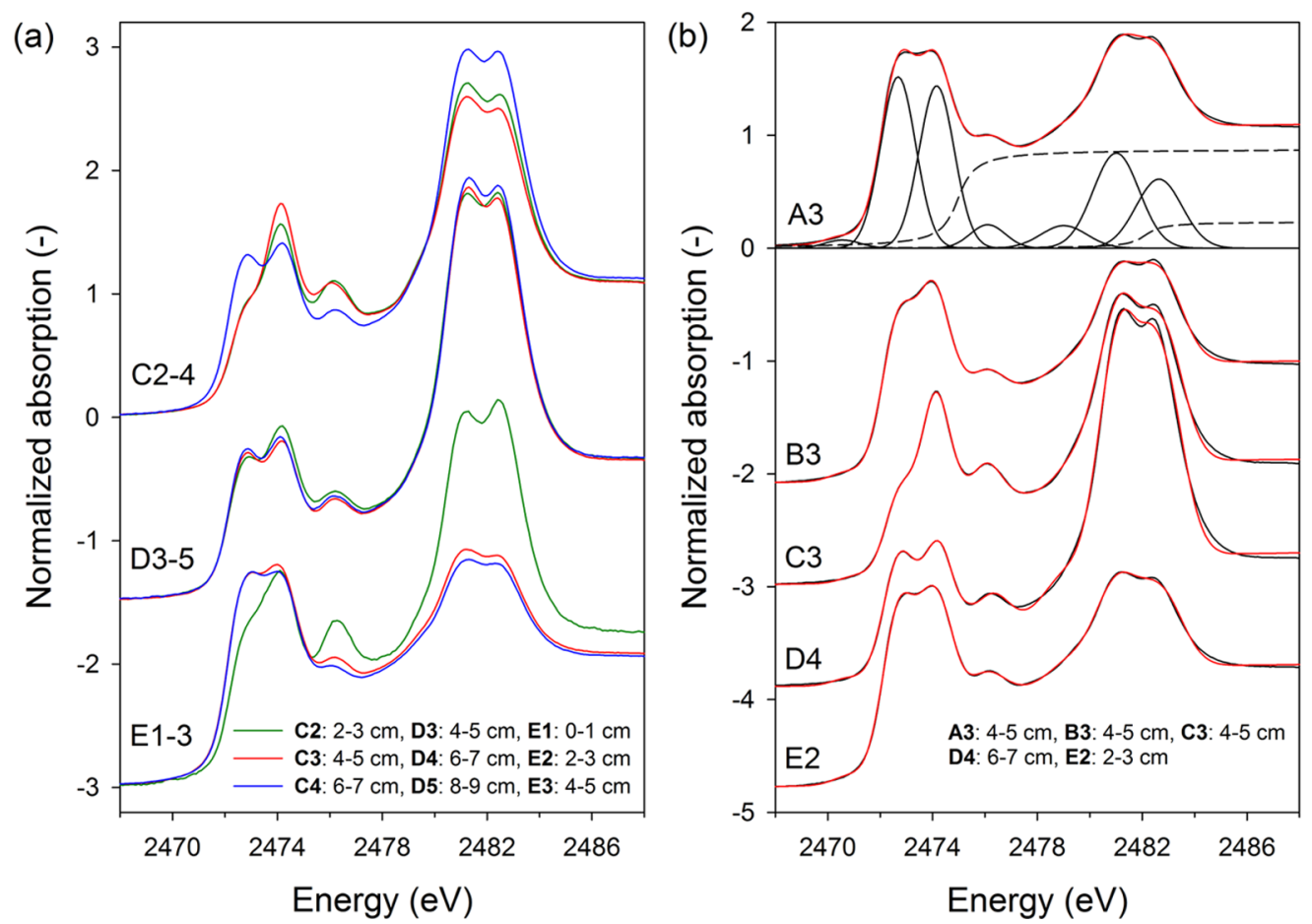

Figure 4. Sulfur speciation in the studied peat samples. (a) Normalized S K-edge XANES spectra of peat samples from sites C-E as a function of sampling depth. (b) Gaussian curve fits of selected peat spectra. Experimental data are shown as black and fit envelopes as red lines. The spectral decomposition is exemplarily illustrated for sample A3. The two arctan functions are shown as dashed lines and the Gaussian peaks correspond to (from left to right) inorganic sulfide, exocyclic/elemental, heterocyclic, sulfoxide, sulfone, sulfonate, and sulfate S. The fit parameters for all samples are reported in Table S9.

reduction reactions, leading to the formation of volatile (methyl)arsines. As a consequence, $\mathrm{MMA}(\mathrm{V})$ and $\mathrm{DMA}(\mathrm{V})$ are frequently identified as metabolites in bacteria. ${ }^{41}$

Our LCF analyses also revealed that an As fraction of $\leq 20 \%$ in the peat existed as $S_{\text {org }}$-bound As(III) (Table 1). This result is similar to findings obtained by Langner et al. ${ }^{11,12}$ for a minerotrophic peatland, in which up to $44 \%$ of total As was bound as As(III) to sulfhydryl groups of peat OM at depths $<35 \mathrm{~cm}$. Organosulfur-coordinated As(III) in our peat samples suggests that As taken up by microorganisms and/or peatforming plants through phosphate transporters (arsenate) or aquaporin channels (arsenite) is detoxified via binding to sulfhydryl-rich peptides such as glutathione or phytochelatines. $^{47,48}$ Alternatively, arsenite may bind to sulfhydryl-rich peat $\mathrm{OM}$ under reducing conditions without direct biological influence. ${ }^{13}$ In summary, our speciation analysis implies that organoarsenicals dominate solid-phase As in all peat samples.

Aqueous-Phase Arsenic Speciation. The geochemical conditions and As speciation in peat bog pore- and streamwaters are summarized in Table 2. The waters were acidic $(\mathrm{pH}$ 4.0-4.4), suboxic $\left(E_{\mathrm{h}}: 165-190 \mathrm{mV}\right)$, and contained $0.66-2.75$ $\mathrm{mg} / \mathrm{L} \mathrm{SO}_{4}$. Total As concentrations in the porewaters were variable, with site averages ranging from 3.0 to $129 \mu \mathrm{g} / \mathrm{L}$. The porewaters contained $4-71 \%$ arsenite, $1-14 \%$ arsenate, $1-15 \%$ arsenobetaine, and $\leq 4 \% \mathrm{MMA}(\mathrm{V})$ and $\mathrm{DMA}(\mathrm{V})$. Interestingly, the porewaters also contained $13-87 \%$ unidentified As species, most likely due to coelution of cationic As species and/or retention of noneluting species on the column. $\mathrm{MMA}(\mathrm{V})$ and 
$\operatorname{DMA}(\mathrm{V})$ were only detected at the wettest sites (Tables 2 and S1). Frequent and persistent saturation at these locations, and associated anoxic conditions, is likely to have facilitated the methylation of As by sulfidogenic and/or methanogenic bacteria. ${ }^{49}$ Conversely, prolonged oxic conditions at sites $\mathrm{C}$ and $\mathrm{D}$, evidenced by lower $\mathrm{Fe}$ and higher $\mathrm{NO}_{3}$ concentrations in porewaters, are likely to have inhibited the formation of MMA(V) and DMA(V). Consistent with lower As biomethylation rates at the drier sites, arsenobetaine accounted for 28$38 \%$ of all organic and unidentified As species, substantially more than the wetter sites (Table 2). The presence of inorganic As in porewaters complies with short half-lives (0.5-12.6 days) determined for $\mathrm{DMA}(\mathrm{V})$ and arsenobetaine in fen soils at $5{ }^{\circ} \mathrm{C}$ as a consequence of demethylation and sorption reactions. ${ }^{50}$

Arsenic concentrations in streamwaters were lower and less variable, with site averages of 1.5-3.2 $\mu \mathrm{g} / \mathrm{L}$. Streamwaters contained $0-29 \%$ arsenite, $27-59 \%$ arsenate, $8-15 \%$ arsenobetaine, and 12-55\% unidentified As species. Arsenobetaine comprised $13-56 \%$ of all organic and unidentified As species (Table 2). Overall, the abundance of organic As species in poreand streamwaters confirms the importance of As biotransformation in the peat as implied by the solid-phase speciation results.

Solid-Phase Iron and Sulfur Speciation. Figure 3a illustrates Fe K-edge XANES spectra of selected Fe reference compounds and peat samples from all sites and a depth of 4-5 $\mathrm{cm}$. The XANES spectra $(n=9)$ exhibited first-derivative maxima at $\sim 7127 \mathrm{eV}$, typical of Fe(III) compounds. Supported by PCA-TT results (see SI), this finding precludes the existence of appreciable amounts of $\mathrm{Fe}$ (II) in the peat. Figure $3 \mathrm{~b}$ shows fits of selected $k^{2}$-weighted EXAFS spectra and Table 3 reports the LCF results for all samples. Accordingly, the peat samples contained between 9 and $100 \%$ organic $\mathrm{Fe}(\mathrm{III})$ complexes $(\bar{x}=$ $68 \%), 0-42 \%$ ferrihydrite $\left(\sim \mathrm{Fe}_{5} \mathrm{HO}_{8} \cdot 4 \mathrm{H}_{2} \mathrm{O}, \bar{x}=17 \%\right)$, and $0-$ $49 \%$ atmospherically deposited hematite $\left(\alpha-\mathrm{Fe}_{2} \mathrm{O}_{3}, \bar{x}=14 \%\right)$. Despite the presence of significant amounts of $\mathrm{Fe}(\mathrm{III})$ minerals in about half of the samples studied by Fe XAS, most of the As was not associated with these phases (Tables 1 and 3). Likewise, although organic $\mathrm{Fe}$ (III) complexes were the dominant $\mathrm{Fe}$ species in the peat, the majority of As was not bound in ternary As-Fe(III)-OM complexes. ${ }^{31,51}$

Sulfur speciation analyses were conducted by Gaussian deconvolution of normalized S K-edge XANES spectra. The spectra were deconvoluted using two arctan functions, the edge steps of reduced and oxidized S species, and seven Gaussian functions representing $S \mathrm{~s} \rightarrow \mathrm{p}$ transition peaks of inorganic sulfide, exocyclic/elemental, heterocyclic, sulfoxide, sulfone, sulfonate, and sulfate S. Figure 4a shows selected S XANES spectra of peat samples from sites C-E as a function of depth, and Figure $4 \mathrm{~b}$ illustrates the spectral deconvolution of selected peat spectra. Two major absorption regions were evident in all samples: The first is characterized by "reduced S" (inorganic sulfide, exocyclic/elemental, and heterocyclic $S$ ) with white-line energies <2474.3 eV; the second accommodates "oxidized S" (sulfonate and sulfate $S$ ) with white-line energies $>2481.0 \mathrm{eV}$ (Figure 4). Reduced S accounted for $58-82 \%(\bar{x}=68 \%)$ and oxidized S for $13-36 \%(\bar{x}=25 \%)$ of total S. With only $5-9 \%$ $(\bar{x}=6 \%)$ of total $S$, the contribution of "intermediate oxidized S" (sulfoxide and sulfone $S$ ) with white-line energies of 2475.9-2479.5 eV was low and likely overestimated due to postedge absorption features of reduced S species ${ }^{52}$ (Table S9). Down-core trends in $\mathrm{S}$ speciation at sites $\mathrm{C}-\mathrm{E}$ were variable (Figure $4 \mathrm{a}$ ). At $<6 \mathrm{~cm}$ depth at site $\mathrm{C}$, exocyclic/elemental $\mathrm{S}$ was depleted $(-10 \%)$ relative to heterocyclic S. At site D we observed no change in the $S$ speciation with depth, whereas at site $\mathrm{E}$ the peat surface $(<1 \mathrm{~cm}$ depth) was depleted in exocyclic/elemental $S(-15 \%)$ and enriched in oxidized $S$ (Figure 4a, Table S10). Samples from the drier C and D sites showed significantly less reduced $S$ in comparison to the wetter A, B, and E sites (Mann-Whitney Rank Sum Test, $p=0.004$ ). This result coincides with the lack of S-coordinated As(III) in the former samples (Table 1). Although reduced $S$ was the dominant $S$ form in the peat, only a small fraction of As was associated with $\mathrm{S}$ and most As prevailed as C-bound As (Table1).

Environmental Implications. Current knowledge on the importance of organoarsenicals in the biogeochemical As cycle in wetlands is largely based on porewater speciation analyses $^{49,53}$ and the quantification of volatile (methyl)arsines emanating from soil. ${ }^{17,18}$ Such analyses have supported the view that As biomethylation is associated with As mobilization and thus a loss of As from soil. In contrast, our spectroscopic analyses revealed that simple and more complex organoarsenicals constitute a substantial portion of solid-phase As in peat bogs subjected to atmospheric deposition of anthropogenically derived As, which has not been reported so far. ${ }^{54,55}$ This finding challenges the current assertion that the efficiency of metal(loid) biomethylation (and biosynthesis) processes in water/sediment systems is generally low compared to the amount of metal(loid) present. $^{56} \mathrm{We}$ found that long-term atmospheric codeposition of inorganic $S$ and As, originating from industrial centers of England, has neither resulted in the in situ formation of As sulfide minerals and the extensive binding of As to organic $S$ under anoxic conditions, nor an appreciable immobilization of As by $\mathrm{Fe}$ (III)-(oxyhydr)oxides under oxic conditions, as frequently observed for naturally As-contaminated wetlands. ${ }^{12,57}$ Instead, long-term As deposition has stimulated extensive As biotransformation reactions in the peat, by which inorganic As is detoxified by microorganisms. The accumulation of organic As in the peat under anoxic conditions is expected to decouple the biogeochemical cycles of As and Fe since microbial Fe(III) reduction would hardly affect the stability of organoarsenicals in the peat. As a result, the vertical postdepositional mobility of As in peat bogs is limited under conditions of sustained water saturation. However, water table drawdown and subsequent peat oxidation may stimulate demethylation reactions and cause the lateral migration of inorganic $\mathrm{As}$ as evidenced at the wetter sites $\mathrm{A}, \mathrm{B}$, and $\mathrm{E}$ (Figure1, Tables 1 and 2). The mobilization of inorganic As under oxic conditions, its lateral migration into wetter, more reducing, and $\mathrm{S}$-rich zones facilitates biomethylation reactions, which is corroborated by high proportion of organic As (62\% of $\left.\mathrm{A} s_{\text {tot }}\right)$ in the top centimeter at site E. These organoarsenicals must have formed during the last one or two decades given a peat accumulation rate in this area of $0.5-1 \mathrm{~mm} / \mathrm{y}^{21}$

The abundance of organoarsenicals provides the first molecular-level explanation for the generally high stability and preservation of As in ombrotrophic peatlands, which facilitates their use as archives of historical atmospheric As deposition. ${ }^{5,6,58,59}$ In summary, our results document that microbial organoarsenical formation can be a quantitatively important As immobilization pathway in wetlands, suggesting that the significance of organometal(loid)s in wetlands subjected to gross air pollution is higher than previously thought. 


\section{ASSOCIATED CONTENT}

\section{S Supporting Information}

The Supporting Information is available free of charge on the ACS Publications website at DOI: 10.1021/acs.est.5b06182.

Details on site and sample characteristics, XAS data collection, reduction and analyses, peat extractions, and aqueous-phase measurements (PDF)

\section{AUTHOR INFORMATION}

\section{Corresponding Author}

*Phone: +45-35334364; e-mail: mikutta@plen.ku.dk.

\section{Notes}

The authors declare no competing financial interest.

\section{ACKNOWLEDGMENTS}

We thank K. Barmettler for his support in the soil chemistry laboratory at ETH Zurich, and J. Moore, J. Yarwood, P. Lythgoe, A. Bewsher, J. Fellowes, and K. Theis for technical assistance at The University of Manchester. Use of the Stanford Synchrotron Radiation Lightsource, SLAC National Accelerator Laboratory, is supported by the U.S. Department of Energy, Office of Science, Office of Basic Energy Sciences under contract No. DE-AC02-76FS00515. We are grateful to R. Davis for his support in using beamlines 4-1 and 11-2, and E. Nelson and M. Latimer for their assistance at beamline 4-3. ETH Zurich and The University of Manchester are acknowledged for financial support.

\section{REFERENCES}

(1) Rydin, H.; Jeglum, J. K., Peatlands around the world. In The Biology of Peatlands; Rydin, H., Jeglum, J. K., Eds.; Oxford University Press: Oxford, 2006; pp 216-238.

(2) Shotyk, W.; Weiss, D.; Appleby, P. G.; Cheburkin, A. K.; Frei, R; Gloor, M.; Kramers, J. D.; Reese, S.; Van Der Knaap, W. O. History of atmospheric lead deposition since $12,370{ }^{14} \mathrm{C} \mathrm{yr}$ BP from a peat bog, Jura Mountains, Switzerland. Science 1998, 281, 1635-1640.

(3) Tipping, E.; Rieuwerts, J.; Pan, G.; Ashmore, M. R.; Lofts, S.; Hill, M. T. R.; Farago, M. E.; Thornton, I. The solid-solution partitioning of heavy metals $(\mathrm{Cu}, \mathrm{Zn}, \mathrm{Cd}, \mathrm{Pb})$ in upland soils of England and Wales. Environ. Pollut. 2003, 125, 213-225.

(4) Novak, M.; Zemanova, L.; Voldrichova, P.; Stepanova, M.; Adamova, M.; Pacherova, P.; Komarek, A.; Krachler, M.; Prechova, E. Experimental evidence for mobility/immobility of metals in peat. Environ. Sci. Technol. 2011, 45, 7180-7187.

(5) Shotyk, W. Natural and anthropogenic enrichments of $\mathrm{As}, \mathrm{Cu}$, $\mathrm{Pb}, \mathrm{Sb}$, and $\mathrm{Zn}$ in ombrotrophic versus minerotrophic peat bog profiles, Jura Mountains, Switzerland. Water, Air, Soil Pollut. 1996, 90, 375-405.

(6) MacKenzie, A. B.; Logan, E. M.; Cook, G. T.; Pulford, I. D. A historical record of atmospheric depositional fluxes of contaminants in west-central Scotland derived from an ombrotrophic peat core. Sci. Total Environ. 1998, 222, 157-166.

(7) Rothwell, J. J.; Taylor, K. G.; Ander, E. L.; Evans, M. G.; Daniels, S. M.; Allott, T. E. H. Arsenic retention and release in ombrotrophic peatlands. Sci. Total Environ. 2009, 407, 1405-1417.

(8) Dittmar, J.; Voegelin, A.; Roberts, L. C.; Hug, S. J.; Saha, G. C.; Ali, M. A.; Badruzzaman, A. B. M.; Kretzschmar, R. Spatial distribution and temporal variability of arsenic in irrigated rice fields in Bangladesh. 2. Paddy soil. Environ. Sci. Technol. 2007, 41, 5967-5972.

(9) Rothwell, J. J.; Taylor, K. G.; Evans, M. G.; Allott, T. E. H. Contrasting controls on arsenic and lead budgets for a degraded peatland catchment in Northern England. Environ. Pollut. 2011, 159, 3129-3133.

(10) Ferguson, P.; Lee, J. A. Past and present sulphur pollution in the southern Pennines. Atmos. Environ. 1983, 17, 1131-1137.
(11) Langner, P.; Mikutta, C.; Suess, E.; Marcus, M. A.; Kretzschmar, R. Spatial distribution and speciation of arsenic in peat studied with microfocused X-ray fluorescence spectrometry and X-ray absorption spectroscopy. Environ. Sci. Technol. 2013, 47, 9706-9714.

(12) Langner, P.; Mikutta, C.; Kretzschmar, R. Arsenic sequestration by organic sulphur in peat. Nat. Geosci. 2012, 5, 66-73.

(13) Hoffmann, M.; Mikutta, C.; Kretzschmar, R. Bisulfide reaction with natural organic matter enhances arsenite sorption: Insights from X-ray absorption spectroscopy. Environ. Sci. Technol. 2012, 46, 1178811797.

(14) Branfireun, B. A.; Roulet, N. T.; Kelly, C. A.; Rudd, J. W. M. In situ sulphate stimulation of mercury methylation in a boreal peatland: Toward a link between acid rain and methylmercury contamination in remote environments. Global Biogeochem. Cycles 1999, 13, 743-750.

(15) Åkerblom, S.; Bishop, K.; Björn, E.; Lambertsson, L.; Eriksson, T.; Nilsson, M. B. Significant interaction effects from sulfate deposition and climate on sulfur concentrations constitute major controls on methylmercury production in peatlands. Geochim. Cosmochim. Acta 2013, 102, 1-11.

(16) Mestrot, A.; Planer-Friedrich, B.; Feldmann, J. Biovolatilisation: A poorly studied pathway of the arsenic biogeochemical cycle. Environ. Sci.: Processes Impacts 2013, 15, 1639-1651.

(17) Mestrot, A.; Feldmann, J.; Krupp, E. M.; Hossain, M. S.; Roman-Ross, G.; Meharg, A. A. Field fluxes and speciation of arsines emanating from soils. Environ. Sci. Technol. 2011, 45, 1798-1804.

(18) Vriens, B.; Lenz, M.; Charlet, L.; Berg, M.; Winkel, L. H. E. Natural wetland emissions of methylated trace elements. Nat. Commun. 2014, 5, 3035.

(19) Lizama A., K.; Fletcher, T. D.; Sun, G. Removal processes for arsenic in constructed wetlands. Chemosphere 2011, 84, 1032-1043.

(20) Smith, R. A. On the air and rain of Manchester. Mem. Lit. Philos. Soc. Manchester 1852, 2, 207-217.

(21) Rothwell, J. J.; Taylor, K. G.; Chenery, S. R. N.; Cundy, A. B.; Evans, M. G.; Allott, T. E. H. Storage and behavior of As, $\mathrm{Sb}, \mathrm{Pb}$, and $\mathrm{Cu}$ in ombrotrophic peat bogs under contrasting water table conditions. Environ. Sci. Technol. 2010, 44, 8497-8502.

(22) Holden, J.; Burt, T. P. Hydrological studies on blanket peat: The significance of the acrotelm-catotelm model. J. Ecol. 2003, 91, 86-102.

(23) Steinmann, P.; Shotyk, W. Sampling anoxic pore waters in peatlands using "peepers" for in situ-filtration. Anal. Bioanal. Chem. 1996, 354, 709-713.

(24) Jahnke, R. A. A simple, reliable, and inexpensive pore-water sampler. Limnol. Oceanogr. 1988, 33, 483-487.

(25) Yafa, C.; Farmer, J. G.; Graham, M. C.; Bacon, J. R.; Barbante, C.; Cairns, W. R. L.; Bindler, R.; Renberg, I.; Cheburkin, A.; Emons, H.; et al. Development of an ombrotrophic peat bog (low ash) reference material for the determination of elemental concentrations. J. Environ. Monit. 2004, 6, 493-501.

(26) Ravel, B.; Newville, M. ATHENA, ARTEMIS, HEPHAESTUS: Data analysis for X-ray absorption spectroscopy using IFEFFIT. J. Synchrotron Radiat. 2005, 12, 537-541.

(27) Manceau, A.; Marcus, M. A.; Tamura, N., Quantitative speciation of heavy metals in soils and sediments by synchrotron $\mathrm{X}$ ray techniques. In Applications of Synchrotron Radiation in LowTemperature Geochemistry and Environmental Science; Fenter, P. A., Rivers, M. L., Sturchio, N. C., Sutton, S. R., Eds.; Mineralogical Society of America and Geochemical Society: Washington DC, 2002; pp 341428.

(28) Webb, S. M. SIXPack: A graphical user interface for XAS analysis using Ifeffit. Phys. Scr. 2005, T115, 1011-1014.

(29) Ressler, T. WinXAS: A program for X-ray absorption spectroscopy data analysis under MS-Windows. J. Synchrotron Radiat. 1998, 5, 118-122.

(30) Waychunas, G. A.; Rea, B. A.; Fuller, C. C.; Davis, J. A. Surface chemistry of ferrihydrite: Part 1. EXAFS Studies of the geometry of coprecipitated and adsorbed arsenate. Geochim. Cosmochim. Acta 1993, $57,2251-2269$. 
(31) Mikutta, C.; Kretzschmar, R. Spectroscopic evidence for ternary complex formation between arsenate and ferric iron complexes of humic substances. Environ. Sci. Technol. 2011, 45, 9550-9557.

(32) Farquhar, M. L.; Charnock, J. M.; Livens, F. R.; Vaughan, D. J. Mechanisms of arsenic uptake from aqueous solution by interaction with goethite, lepidocrocite, mackinawite, and pyrite: An X-ray absorption spectroscopy study. Environ. Sci. Technol. 2002, 36, $1757-1762$.

(33) Cannon, J. R.; Edmonds, J. S.; Francesconi, K. A.; Raston, C. L.; Saunders, J. B.; Skelton, B. W.; White, A. H. Isolation, crystal structure and synthesis of arsenobetaine, a constituent of the western rock lobster, the dusky shark, and some samples of human urine. Aust. J. Chem. 1981, 34, 787-798.

(34) Betz, R.; McCleland, C.; Marchand, H. The monoclinic polymorph of dimethylarsinic acid. Acta Crystallogr., Sect. E: Struct. Rep. Online 2011, E67, m1013.

(35) Voegelin, A.; Weber, F.-A.; Kretzschmar, R. Distribution and speciation of arsenic around roots in a contaminated riparian floodplain soil: Micro-XRF element mapping and EXAFS spectroscopy. Geochim. Cosmochim. Acta 2007, 71, 5804-5820.

(36) Kuehnelt, D.; Lintschinger, J.; Goessler, W. Arsenic compounds in terrestrial organisms. IV. Green plants and lichens from an old arsenic smelter site in Austria. Appl. Organomet. Chem. 2000, 14, 411420.

(37) Geiszinger, A.; Goessler, W.; Kosmus, W. Organoarsenic compounds in plants and soil on top of an ore vein. Appl. Organomet. Chem. 2002, 16, 245-249.

(38) Dembitsky, V. M.; Rezanka, T. Natural occurrence of arseno compounds in plants, lichens, fungi, algal species, and microorganisms. Plant Sci. 2003, 165, 1177-1192.

(39) Schaeffer, R.; Francesconi, K. A.; Kienzl, N.; Soeroes, C.; Fodor, P.; Váradi, L.; Raml, R.; Goessler, W.; Kuehnelt, D. Arsenic speciation in freshwater organisms from the river Danube in Hungary. Talanta 2006, 69, 856-865.

(40) Ruiz-Chancho, M. J.; López-Sánchez, J. F.; Schmeisser, E.; Goessler, W.; Francesconi, K. A.; Rubio, R. Arsenic speciation in plants growing in arsenic-contaminated sites. Chemosphere 2008, 71, 15221530.

(41) Huang, J.-H. Impact of microorganisms on arsenic biogeochemistry: A review. Water, Air, Soil Pollut. 2014, 225, 1848.

(42) Caumette, G.; Koch, I.; Estrada, E.; Reimer, K. J. Arsenic speciation in plankton organisms from contaminated lakes: Transformations at the base of the freshwater food chain. Environ. Sci. Technol. 2011, 45, 9917-9923.

(43) ThomasArrigo, L. K.; Mikutta, C.; Byrne, J.; Barmettler, K.; Kappler, A.; Kretzschmar, R. Iron and arsenic speciation and distribution in organic flocs from streambeds of an arsenic-enriched peatland. Environ. Sci. Technol. 2014, 48, 13218-13228.

(44) Elliott, D. R.; Caporn, S. J. M.; Nwaishi, F.; Nilsson, R. H.; Sen, R. Bacterial and fungal communities in a degraded ombrotrophic peatland undergoing natural and managed re-vegetation. PLoS One 2015, 10, e0124726.

(45) Caumette, G.; Koch, I.; Reimer, K. J. Arsenobetaine formation in plankton: A review of studies at the base of the aquatic food chain. $J$. Environ. Monit. 2012, 14, 2841-2853.

(46) Henke, K. R.; Hutchison, A., Arsenic chemistry. In Arsenic: Environmental Chemistry, Health Threats and Waste Treatment; Henke, K. R., Ed.; John Wiley \& Sons, Ltd, 2009; pp 9-68.

(47) Mukhopadhyay, R.; Rosen, B. P.; Phung, L. T.; Silver, S. Microbial arsenic: From geocycles to genes and enzymes. FEMS Microbiol. Rev. 2002, 26, 311-325.

(48) Zhao, F. J.; Ma, J. F.; Meharg, A. A.; McGrath, S. P. Arsenic uptake and metabolism in plants. New Phytol. 2009, 181, 777-794.

(49) Huang, J.-H.; Matzner, E. Dynamics of organic and inorganic arsenic in the solution phase of an acidic fen in Germany. Geochim. Cosmochim. Acta 2006, 70, 2023-2033.

(50) Huang, J.-H.; Scherr, F.; Matzner, E. Demethylation of dimethylarsinic acid and arsenobetaine in different organic soils. Water, Air, Soil Pollut. 2007, 182, 31-41.
(51) Hoffmann, M.; Mikutta, C.; Kretzschmar, R. Arsenite binding to natural organic matter: Spectroscopic evidence for ligand exchange and ternary complex formation. Environ. Sci. Technol. 2013, 47, 12165-12173.

(52) Manceau, A.; Nagy, K. L. Quantitative analysis of sulfur functional groups in natural organic matter by XANES spectroscopy. Geochim. Cosmochim. Acta 2012, 99, 206-223.

(53) Zhao, F.-J.; Harris, E.; Yan, J.; Ma, J.; Wu, L.; Liu, W.; McGrath, S. P.; Zhou, J.; Zhu, Y.-G. Arsenic methylation in soils and its relationship with microbial arsM abundance and diversity, and As speciation in rice. Environ. Sci. Technol. 2013, 47, 7147-7154.

(54) Smedley, P. L.; Kinniburgh, D. G. A review of the source, behaviour and distribution of arsenic in natural waters. Appl. Geochem. 2002, 17, 517-568.

(55) Zhang, H.; Selim, H. M. Reaction and transport of arsenic in soils: Equilibrium and kinetic modeling. Adv. Agron. 2008, 98, 45-115.

(56) Dopp, E.; Hartmann, L. M.; Florea, A.-M.; Rettenmeier, A. W.; Hirner, A. V. Environmental distribution, analysis, and toxicity of organometal(loid) compounds. Crit. Rev. Toxicol. 2004, 34, 301-333.

(57) Blodau, C.; Fulda, B.; Bauer, M.; Knorr, K.-H. Arsenic speciation and turnover in intact organic soil mesocosms during experimental drought and rewetting. Geochim. Cosmochim. Acta 2008, 72, 39914007.

(58) Ukonmaanaho, L.; Nieminen, T. M.; Rausch, N.; Shotyk, W. Heavy metal and arsenic profiles in ombrogenous peat cores from four differently loaded areas in Finland. Water, Air, Soil Pollut. 2004, 158, 277-294.

(59) Cloy, J. M.; Farmer, J. G.; Graham, M. C.; MacKenzie, A. B. Retention of As and $\mathrm{Sb}$ in ombrotrophic peat bogs: Records of As, $\mathrm{Sb}$, and $\mathrm{Pb}$ deposition at four Scottish sites. Environ. Sci. Technol. 2009, 43, $1756-1762$.

(60) Kelly, S. D.; Hesterberg, D.; Ravel, B., Analysis of soils and minerals using X-ray absorption spectroscopy. In Methods of Soil Analysis. Part 5: Mineralogical Methods; Ulery, A. L., Drees, L. R., Eds.; Soil Science Society of America: Madison, WI, 2008; pp 387-463. 